QUALITY

Volume 5, Nomor 2, 2017: 386-402

\title{
MENGCOUNTER HOAX MELALUI INTERNALISASI NILAI NILAI PENDIDIKAN ISLAM
}

\author{
Farid Khoeroni \\ Dosen STAIN Kudus \\ faridvcc@gmail.com
}

\begin{abstract}
Abstrak
Tujuan dari penelitian ini adalah untuk mengetahui hoax dan dampaknya bagi masyarakat serta cara mengcounter hoax dengan internalisasi pendidikan Islam. penelitian yang digunakan adalah metode deskriptif kualitatif dirancang untuk mengumpulkan informasi tentang keadaan-keadaan yang sementara berlangsung. Hoax dapat dicounter melalui internalisasi nilai nilai pendidikan Islam, teknisnya ada dua tahap. Pertama: transformasi nilai nilai pendidikan Islam dan kedua adalah tahapan aplikatif berorientasi pada perbaikan sikap dan akhlak.

Kata Kunci: Hoax, Internalisasi, Nilai

Abstract

The purpose of study is to know the hoax and its impact for the community and how to counter hoax with the internalization of Islamic education. the research used is a qualitative descriptive method designed to collect information about ongoing situations. Hoax can be countered by the internalization of the value of Islamic education, technical there are two stages. First: the transformation of the value of Islamic education and the second is the applicative stage oriented to the improvement of attitudes and morals.
\end{abstract}

Keywords: Hoax, Internalization, Value

\section{A. Pendahuluan}

Tema hoax sebenarnya bukanlah tema asing, sebab term tersebut sering menjadi bahan perbincangan dikalangan masyarakat, bahkan masyarakat awam sekalipun juga mengenal kata hoax (=bukan subtansi hoax). Entah mereka tahu betul tentang arti yang pasti tentang hoax atau hanya mengikuti arus yang terus mengalir dari kebanyakan masyarakat tentang hoax, dan serta menggunakan kata tersebut dalam perbincangan yang mengarah pada berita yang tidak benar. Meskipun demikian hoax sudah menjadi bahan pembicaraan secara verbal oleh kalangan masyarakat secara keseluruhan. 


\section{Farid Khoeroni}

Berita tidak benar atau sesuatu yang dikabarkan tidak semestinya dan atau sesuatu yang tidak dapat dikroscek kebenarannya merupakan kategori hoax. hoax yang saat ini menjadi bagian dari pembicaraan sehari hari masyarakat merupakan sesuatu yang tidak biasa saja, masyarakat menjadikan tema hoax sebagai pembicaraanya karena tema tersebut mempunyai pengaruh yang cukup besar bagi masyarakat. Masyarakat secara langsung mempercayai konten hoax tanpa ada proses klarifikasi atau mengkroscek sumber kebenarannya.

Masyarakat akhir akhir ini sering diresahkan atas berita yang tidak benar yang bersumber dari baerbagai macam informasi yang tidak dapat dipertanggung jawabkan. Selain itu hoax juga mempunyai style dan karakter yang berbeda-beda, sehingga masyarakat awam sulit untuk mengenalinya.Kebanyakan dari masyarakat cenderung mempercayai berita yang belum terkroscek kebenarannya. Cepatnya arus informasi yang bersumber dari internet, kabar atau berita tersebut dengan cepat sampai kepada masyarakat secara luas. Atas cepatnya arus informasi yang beredar, masyarakat sulit untuk mengidentifikasi serta mengkroscek kebenarannya, sumber kebenaran menjadi barang mahal karena informasi yang valid sulit untuk terlacak. Masyarakat sulit mencari informasi yang benar benar valid. Keterbatasanlah yang menjadi penyebab untukmengakses informasi untuk memperoleh berita valid.

Ketidakbenaransuatu beritaakan berefek pada kehidupan masyarakat secara lebih luas, jauh hari sebelum hoax ramai menjadi pembicaraan dari berbagai kalangan. Hoax sebenarnya sudah ada jauh hari sebelum ramai diperbincangkan. Hanya saja terdapat perbedaan dari efek yang ditimbulkan dari hoax tersebut, yaitu berpengaruh secara luas atau tidak. dampaknya sangat sulit diprediksi. Ketika berbicara hoax dalam skala lebih kecil bisa jadi tidak akan berdampak apapun dalam kehidupan bermasyarakat, namun ketika hoax tersebut sudah menyasar pada isu sensitif semisal isu SARA maka dampak yang ditimbulkan akan jauh lebih berbahaya.

Undang-Undang Nomor 11 Tahun 2008 tentang Informasi dan Transaksi mengatur hal tersebut dalam Pasal 28 ayat (1), yang berbunyi: "Setiap Orang dengan 


\section{Farid Khoeroni}

sengaja dan tanpa hak menyebarkan berita bohong dan menyesatkan yang mengakibatkan kerugian konsumen dalam transaksi Elektronik." Ancaman pidana dari pasal tersebut disebutkan dalam Pasal 45 ayat (2) UU ITE yaitu hukuman penjara selama 6 (enam) tahun dan atau denda paling banyak Rp 1 miliar. Sangat jelas bahwa menyebarkan berita hoax atau berita tidak benar akan dikenakan sanksi hukuman serta denda yang tidak sedikit. Meskipun demikian, masih terdapat oknum yang berkepentingan untuk menyebarkan berita hoax.

Banyak opsi untuk memerangi hoax yang beredar di masyarakat. selain Undang Undang yang telah lama memproteksi masyarakat, banyak penyedia layanan yang memberikan solusi untuk memfilter jenis berita hoax. Dalam jurnal "Web Klarifikasi Berita Untuk Meminimalisir Penyebaran Berita Hoax" menyebutkan bahwa berita tidak benar (hoax) dapat dideteksi menggunakan jenis layanan aplikasi web, web tersebut dapat mengetahui berita yang ada termasuk dalam kategori hoax atau tidak (Firmansyah, 2017). Persoalannya adalah terkait dengan efektifitas. Tidak semua masyarakat dapat mengoperasikan teknisnya, apalagi masyarakat awam. Sehingga banyak persoalan lain yang menjadi titik lemah dalam memerangi hoax.

Terkait teknis mengcounter hoax, secara sederhana dapat dicegah menggunakan aplikasi tertentu yang berfungsi untuk mendeteksi content hoax yang menyebar di masyarakat. Kendalanya adalah pemfilteran tersebut tidak dapat menjangkau seluruh masyarakat yang setiap hari mendapati jenis informasi yang tidak dapat dipertanggung jawabkan kebenarannya. Mengcounter hoax menggunakan aplikasi tertentu cukup efektif dalam skala kecil, tidak dalam skala yang lebih besar.

Opsi lain mengcuonter hoax adalah dengan menerapkan prinsip prinsip pendidikan yang bersumber dari Quran dan Hadits yang telah terkonsep menjadi nilai nilai pendidikan Islam. Pendidikan Islam berperan penting dalam mewujudkan Islam Rahmatan lil Alamin dan juga membentuk masyarakat madani yang beradab. Sejak jauh jauh hari, pendidikan Islam telah mampu memberikan sumbangsih dalam mewujudkan peradaban Islam yang saat ini masih temaktub dalam buku buku sejarah. Selain itu sumbangsih dalam hal keilmuan juga memberikan cerita menarik 


\section{Farid Khoeroni}

pada abad keemasan Islam. Islam mampu menjadi barometer bagi peradaban dunia pada masanya.

Idealnya, jika Islam mampu mewujudkan peradaban dunia melalui Pendidikan Islam dan mampu mencetak para pemikir Islam yang karyanya masih abadi sampai saat ini. Tentu jika dihadapkan pada permasalahan dan persoalan kecil sebatas hoax, harusnya pendidikan Islam mampu mengcounter hoax melalui Pendidikan Islam itu sendiri. Berdasar pada pemaparan di atas, penelitian ini bertujuanuntuk mengkaji lebih mendalam mengenai hoax yang menjadi persoalan serta dampaknya pada masyarakat. Selain itu, penelitian ini juga bertujuan mengkaji peran pendidikan Islam dalam mengcounter hoax melalui internalisasi nilai-nilai dalam pendidikan Islam itu sendiri.

\section{B. Pembahasan}

\section{Hoax}

Hoax merupakan usaha untuk memanipulasi kabar dan atau berita yang disampaikan kepada objek sasaran meskipun pembawa berita tahu betul bahwa berita yang disampaikan merupakan berita yang tidak benar (Rahadi, 2017:61). Sumber berita hoax dapat bersumber berbagai macam jenis. Kebanyakan berita hoax berasal dari media sosial yang sering diakses oleh masyarakat, melalui ponsel pintar atau sering disebut sebagai smartphone. Masyarakat aktif mengakses jenis informasi yang bersumber dari berbagai macam aplikasi.

Tujuan hoax utamanya adalah memberikan informasi yang tidak benar, motifnya sangat beragam. Mulai dari membentuk opini public sampai pada motif lain yang dianggap sebagai bahan bercanda, dengan content bercanda, mencitrakan pesaing dengan citra tidak baik, bahkan sampai pada penipuan yang berujung pada tindak kejahatan (Rahadi, 2017:61). Apapun motifnya, hoax yang sudh terlanjur sampai kepada masyarakat secara luas akan berdampak pada sesuatu yang tidak baik.Berita tidak valid menyasar kepada masyarakat untuk semua level masyarakat, 


\section{Farid Khoeroni}

tidak ada batasan level tertentu yang terkena dampak dari ketidakbenaran berita yang tersebar secara luas. Seperti survey yang diwartakan oleh media CNN Indonesia:

Tabel A. 1

\section{Hasil Survey Media CNN Indonesia terkait Dampak Hoax}

\begin{tabular}{|l|c|}
\hline \multicolumn{2}{|c|}{$\begin{array}{c}\text { Survey Mastel, Mastel melibatkan 1.116 responden dengan } \\
\text { teknik random sampling }\end{array}$} \\
\hline Kualifikasi Pendidikan S1 & $46.50 \%$ \\
\hline Kualifikasi Pendidikan S2 & $26 \%$ \\
\hline Kualifikasi Pendidikan SMA/SMK & $14.7 \%$ \\
\hline $\begin{array}{l}\text { Mampu mengenali berita hoax 28\% dan 18 \% diantaranya tidak dapat } \\
\text { mengukur kebenaran berita yang didapat }\end{array}$ \\
\hline
\end{tabular}

Berdasarkan survey yang diwartakan CNN bahwa Pendidikan tinggi tidak dapat memberikan jaminan seseorang dapat memfilter tentang berita yang tidak valid. Pendidikan tinggi juga tidak banyak pengaruhnya dalam mengkroscek kebenaran berita. Kebenaran berita menjadi bias dalam era modern. Akan menjadi bahaya jika generasi yang melek pendidikan tidak dapat mengkroscek kebenaran berita.

\section{Dampak Hoax}

Ketidakbenaransuatu beritaakan berefek pada kehidupan masyarakat secara lebih luas, jauh hari sebelum hoax ramai menjadi pembicaraan dari berbagai kalangan. Hoax sebenarnya sudah ada jauh hari sebelum ramai diperbincangkan. Hanya saja terdapat perbedaan dari efek hoax tersebut, yaitu berpengaruh secara luas atau tidak, dampaknya tidak dapat diprediksi. Ketika berbicara hoax dalam skala lebih kecil bisa jadi akan tidak berdampak apapun dalam kehidupan bermasyarakat, namun ketika hoax tersebut sudah menyasar isu SARA maka dampak yang ditimbulkan akan jauh lebih berbahaya.

Survey dari Masyarakat Telematika Indonesia (Mastel) "merilis survei mengenai dampak penyebaran berita palsu atau hoax yang marak terjadi belakangan ini. Hasilnya sekitar $84,5 \%$ responden menyatakan terganggu dengan berita hoax" (Detik.com), sebagian dari masyarakat merasa terganggu atas hoax yang marak 


\section{Farid Khoeroni}

terjadi saat ini, yaitu sebanyak 85 persen. Meskipun banyak terganggu dengan berita yang tidak valid, namun pada kenyataannya juga tidak berusaha untuk mengkroscek informasi yang disampaikan dengan cara yang tidak dibenarkan. Menjadi dilema apabila melihat hoax dari kalangan yang mempunyai kualifikasi lulusan pendidikan tinggi/ perguruan tinggi. Lulusan yang diharapkan sebagai asset sumber daya manusia yang digadang gadang sebaagai estafet kepemimpinan di negeri ini tidak melek terhadap hoax. bahkan menurut survey yang dilakukan oleh Mastel, bahkan hanya sebanyak 28 persen saja yang mampu mengidentifikasi berita hoax. Persentase yang sangat rendah untuk ukuran masyarakat yang melek pendidikan.

Rendahnya persentase kalangan masyarakat berpendidikan terhadap hoax menjadi pukulan yang sangat telak bagi masyarakat Indonesia secara keseluruhan, bahkan bisa dibilang tidak dapat disebut sebagai masyarakat yang beradab jika ukurannya hanya terkait tentang hoax. Masyarakat melek pendidikan saja tidak antusias mengkroscek atau tidak tahu tentang kebenaran hoax. Bisa jadi masyarakat yang kualifikasi pendidikannya rendah akan melihat hoax sebaagai kebenaran yang benar benar benar. Jangankan sampai mengkroscek kebenaran, untuk melihat hoax sebagai sesuatu yang "tidak benar" saja masih menemukan kesulitan yang luar biasa.

Banyak problem tentang hoax bagi masyarakat, problem tersebut pertama: pemfilteran konten hoax, kedua: dampak hoax bagi masyarakat. Problem tentang konten hoax merupakan problem yang paling urgent, disebut urgent karena pemfilteran merupakan syarat yang harus ditempuh untuk memutus konten hoax. Namun mayoritas masyarakat yang tidak mengenali konten hoax menjadi faktor yang paling sulit untuk mewujudkannya. Hoax akan terus berjalan tanpa henti jika tanpa ada usaha untuk memutus konten hoax tersebut. Problem kedua setelah pemfilteran adalah problem tentang dampak hoax bagi kehidupan bermasyarakat. Tentang dampak, dampak merupakan efek dari hoax itu sendiri. Sebenarnya masalah hoax akan selesai jika dari awal sudah ada pemfilteran. Pemfilteran akan mereduksi sumber berita hoax, sehingga konten hoax akan berhenti dan tidak sampai kepada masyarakat. 
Hoax berdampak cukup serius bagi kehidupan bermasyarakat, beberapa akar masalah dari konflik belakangan ini juga bermula dari hoax. Berikut survey tentang dampak hoax bagi kehidupan bermasyarakat.

Tabel A.2

\section{Hasil Survey terkait Dampak Hoax}

\begin{tabular}{|c|c|}
\hline \multicolumn{2}{|c|}{$\begin{array}{l}\text { Survey Mastel: mayoritas hoax didominasi politik dan SARA mencapai } \\
91 \%\end{array}$} \\
\hline \multicolumn{2}{|c|}{$\begin{array}{l}\text { Saluran Penyebaran Penyebaran melalui media sosial dengan persentase } \\
\text { mencapai } 92.40 \%\end{array}$} \\
\hline $\begin{array}{l}\text { Melalui layanan aplikasi pesan, } \\
\text { LINE, WhatsApp dan Teegram }\end{array}$ & Persentase mencapai $62.80 \%$ \\
\hline Situs WEB & Persentase mencapai 34.90\% \\
\hline Televisi & Persentase mencapai $8.70 \%$ \\
\hline Media cetak & Persentase mencapai 5\% \\
\hline E-mail & Persentase mencapai $3.10 \%$ \\
\hline Radio & Persentase mencapai $1.20 \%$ \\
\hline
\end{tabular}

"Dampak hoax ini mengganggu kehidupan mereka (masyarakat) sehari-hari. Bahkan, bisa berpotensi mengganggu kehidupan berbangsa," ucap Ketua Bidang Kebijakan Strategis Mastel, Teguh Prasetya di Lot 8, Kawasan SCBD, Jakarta, Senin, $(13 / 2 / 2017)$ (Detik.com)

Survey tersebut dilakukan secara on-line oleh Mastel serta direspon oleh 1.116 responden dengan variasi usia sebagai berikut.

Tabel A.3

Variasi Usia yang Terkena Dampak Hoax

\begin{tabular}{|c|c|}
\hline $25-40$ tahun & $47,80 \%$ \\
\hline di atas 40 tahun & $25,70 \%$ \\
\hline $20-24$ tahun & $18,40 \%$ \\
\hline $16-19$ tahun & $7,70 \%$ \\
\hline di bawah 15 tahun & $0,40 \%$ \\
\hline
\end{tabular}




\section{Farid Khoeroni}

Dominasi hoax bermula dari media sosial, pengguna media sosial menjadi sasaran utama hoax. Dampaknya adalah keresahan masyarakat. Masyarakat tidak tahu betul bagaimana kroscek kebenaran berita hoax. Sehingga efek yang ditimbulkan adalah gesekan gesekan tertentu yang berkaitan dengan spesifikasi konten hoax. Jika kontennya adalah SARA, maka konflik yang muncul akan lahir adalah seputar SARA yang berdampak pada perpecahan bangsa Indonesia. Konflik yang sangat serius disebabkan karena berita yang tidak dapat dibenarkan validitasnya.

\section{Pendidikan Islam}

Pendidikan merupakan sarana untuk mewujudkan peradaban manusia yang beradab, beretika dan serta mampu menjadi sarana untuk menciptakan masyarakat madani. Dengan pendidikan, manusia mampu mengenali jati dirinya yang sebenar benarnya. Kebutuhan manusia akan adanya pendidikan merupakan syarat mutlak yang harus terpenuhi. Dilihat dari sudut pandang makhluk sosial, manusia memerlukan pendidikan sebagai sandaran hidup dan sebagai modal dasar bermasyarakat.

Fokus pendidikan sebagai sarana menciptakan masyarakat beradab tidak tercipta secara instan, butuh proses yang panjang sehingga pendidikan mampu menjadi garda terdepan mewujudkan masyarakat madani. Dengan alasan tersebut, tentunya pendidikan yang diharapkan menjadi garda terdepan harus dirumuskan dengan prinsip Rahmatan Lil Alamiin. Maka dari itu Pendidikan Islam menjadi tanggung jawab semua pihak yang berkepentingan. Diantaranya keluarga sebagai lingkunagn yang membentuk karakter pada tingkat pertama. Masyarakat selain sebagai pengguna, pada saat yang sama juga sebagai pelaku dari pendidikan itu sendiri. Dan pemerintah sebagai penentu kebijakan juga mempunyai peran dan tanggung jawab yang sangat besar untuk mempproteksi pendidikan itu sendiri dengan berbagai kebijakan kebijakan. 


\section{Farid Khoeroni}

Pendidikan dan Pendidikan Islam secara sederhana dapat dibedakan dengan akar katanya, yaitu kata pendidikan dengan kata Islam. Ciri khas Islam yang menjadi pembeda antara pendidikan secara umum dengan pendidikan yang berbasis pada Islam. Hal itulah yang membedakan antara konsep pendidikan Islam dengan knsep pendidikan secara umum (Bawani, 1990:59).Kedudukan kata Islam sebagai kunci dalam istilah tersebut dapat dijelaskan sebagai pembeda dengan konsep Pendidikan Islam lainnya. "Dalam ajaran Islam memang benar terdapat konsep Pendidikan Islam, maka konsep yang Pendidikan Islam yang mengacu dari sumber ajaran Islam itulah Pendidikan Islam (Bawani, 1990: 1959). merujuk pada pengertian tersebut maka dapat dikatakan juga bahwa Pendidikan Islam yang tidak sesuai dengan ajaran Islam bukanlah Pendidikan Islam.Dalam Bahasa Arab ada beberapa istilah yang digunakan dalam pengertian Pendidikan Islam. Pertama:"tarbiyah masdar dari rabba serumpun dengan akar kata rabb (Tuhan) oleh karenanya tarbiyah yang berarti mendidik dan memelihara, implisit di dalamnya istilah rabb (Tuhan) sebagai Rabb AlAmin"'(Ahmadi, 2005: 26). Dalam penjelasan lain kata Al-Tarbiyah berasal dari kata (1) Rabba-yarbu yang berarti bertambah, tumbuh dan berkembang, (2) rabiya-yarba berarti menjadi besar, (3) rabba-yarubbu berarti "memperbaiki, menguasai urusan, menuntun dan memelihara" (Nakhlawi, 1992: 31), uraian di atas mengisyaratkan bahwa proses Pendidikan Islam adalah bersumber pada Pendidikan Islam yang diberikan Allah sebagai pendidik seluruh ciptaannya termasuk manusia. Penggunaan tarbiyah untuk menunjuk makna Pendidikan Islam dapat dipahami dengan merujuk firman Allah surat Al-Isra' ayat 24

"dan rendahkanlah dirimu terhadap mereka berdua dengan penuh kesayangan dan ucapkanlah: Wahai Tuhanku, kasihilah mereka keduanya, sebagaimana mereka berdua telah mendidik aku waktu kecil". (QS. Al-Isra':24) (Depag RI, 2000: 335)

Kedua:Al-Ta'lim Al-ta''lim berasal dari kata 'allama yang berarti mengajar, dan menjadikan yakin dan mengetahui. Abdul Fattah Jalal, "Al-Ta'lim sebagai proses pemberian pengetahuan, pemahaman, pengertian, tanggung jawab dan pemahaman 


\section{Farid Khoeroni}

amanah sehingga pensucian atau pembersihan diri manusia itu berada dalam suatu kondisi yang memungkinkan untuk menerima al-hikmah serta mempelajari segala apa yang bermanfaat baginya dan yang tidak diketahuinya" (Jalal, 1998: 26),

Ketiga: Al-Ta'dib berasal dari kata addaba yang artinya membuatkan makanan, melatih dengan akhlak yang baik, sopan santun dan tata cara pelaksanaan sesuatu yang baik menurut Naquib Al-Attasyang dikutip Achmadi, istilah " $t a$ 'dib mencakup ilmu dan amal yang merupakan esensi Pendidikan Islam" (Ahmadi, 2005: 26), waalaupun ketiga istilah itu yakni tarbiyah, ta'lim, ta'dib bisa dipergunakan namun menurut Al-Attas dalam langgulung, berpendapat bahwa ta'lim tidak hanya berarti pengajaran. Menurut Abdul Wahab Jalal, apa yang dilakukan rasul bukan hanya sekedar membuat umat Islam bisa membaca melainkan membawa kaum muslimin kepada nilai Pendidikan Islam TazkiyahAn-Nafs (pensucian diri) dari segala kotoran sehingga memungkinkannya menerima al-Hikmah serta mempelajari segala yang bermanfaat untuk diketahui.

Keempat:al-Ta'dib, Istilah al-Ta'dib menurut Muhammad Naquib al-Attas yang dikutip Achmadi, istilah al-ta'dib untuk konsep Pendidikan Islam, bukan tarbiyah, dengan alasan bahwa dalam Istilah ta'dib mencakup alasan ilmu dan amal yang menyerupai esensi pendidikan Islam. Walaupun ketiga istilah itu yakni, Tarbiyah, Ta'lim dan Ta'dib bisa dipergunakan dengan pengertian yang sama, tetapi menurut Al-Attas yang dikutip Hasan Langgulung, berpendapaat bahwa Ta'lim tak hanya berarti "pengajaran, jadi lebih sempit dari pendidikan Islam, sedang kata tarbiyah yang lebih luas digunakan sekarang di negara-negara berbahasa arab terlalu luas" (Langgulung, 1992: 5), sebab kata Tarbiyah juga digunakan untuk bintang dan tumbuh-tumbuhan dengan pengertian pemeliharaan, membela, menternak dan lainlain.Jadi kata ta'dib, "lebih tepat sebab tidak terlalu sempit sekedar mengajar saja dan tidak meliputi makhluk-makhluk lain selain manusia, ta'dib sudah meliputi kata ta'lim dan tarbiyah, selain itu kata $t a$ 'dib erat hubungannya dengan kondisi ilmu dalam Islam yang termasuk dalam isi pendidikan Islam” (Langgulung, 1992: 5) 


\section{Farid Khoeroni}

Selama ini ada anggapan bahwa pendidikan Islam hanya berkutat untuk mempelajari ilmu-ilmu agama saja, sedang ilmu pengetahuan umum atau yang berhubungan dengan keduniaan nyaris tak tersentuh sama sekali, tapi banyak kalangan atau tokoh-tokoh Islam yang mulai membuka diri dengan melakukan pembaharuan dan menganggap bahwa Pendidikan Islam tidak hanya mempelajari ilmu agama saja seperti yang sudah berlangsung setelah mundurnya peraadaban Islam.

Sebelum membahas lebih jauh pengertian Pendidikan Islam menurut para ahli Pendidikan Islam, disini akan dipaparkan, bahwa dalam Pendidikan Islam terdapat istilah

Menurut Ahmad D Marimba yang dimaksud pendidikan Islam dalam arti sempit adalah "bimbingan yang diberikan kepada anak-anak sampai dewasa, Pendidikan Islam dalam arti luas ialah bimbingan yang diberikan sampai mencapai tujuan hidupnya, bagi Pendidikan Islam, sampai terbentuknya kepribadian muslim" (Marimba, 1980: 31), jadi Pendidikan Islam, berlangsung sejak anak dilahirkan sampai mencapai kesempurnaannya atau sampai akhir hidupnya. Dibawah ini akan dideskripsikan definisi Pendidikan Islam menurut para ahli dibidangnya yang telah memformulasikan pemikirannya tentang Pendidikan Islam sebagai berikut.

\section{Dasar Pendidikan Islam}

Dasar Pendidikan Islam merupakan landasan yang menjadi sumber kekuatan dan keteguhan agar Pendidikan Islam tetap kuat. Ahmad D Marimba mengemukakan, dasar Pendidikan Islam adalah firmn Tuhan dan sunnah Rosulullah SAW. "Kalau Pendidikan Islam diibaratkan bangunan maka, isi Al-Qur'an dan Haditslah yang menjadi fundamentalnya Al-Qur'an adalah sumber kebenaran dalam Islam, kebenarannya tidak dapat diragukan lagi, sedangkan sunah Rosulullah ialah perilaku, ajaran-ajaran dan perkenaan-perkenaan Rasulullah sebagai pelakasana hukum-hukum yang terkandung dalam Al-Qur'an. 


\section{Farid Khoeroni}

Menetapkan Al-Qur'an dan Hadits sebagai dasar Pendidikan Islam bukan hanya dipandang sebagai kebenaran yang didasarkan keimanan semata, namun justru karena kebenaran yang terdapat dalam kedua dasar tersebut dapat diterima oleh nalar manusia dan dapat dibuktikan dalam sejarah atau pengalaman kemanusiaan. Begitu juga dengan Hadits sebagai dasar bagi Pendidikan Islam karena kepribadian Rasul sebagai Uswat Al-Hasanah, suri Tauladan yang baik.Uraian di atas mengandung pengertian bahwa dasar pendidikan Islam bersumber pada Al -Qur'an dan hadits. Qur'an dan Hadits merupakan sumber yang menjadi rujukan pendidikan Islam sehingga dapat ayat ayat Quran dan haditas dapat dieksplorasi sebagai sumebr utama pendidikan Islam.

Beberapa ayat yang menjelaskan tenang Pendidikan Islam dalam Al-Qur'an surat A-mujadalah ayat:11

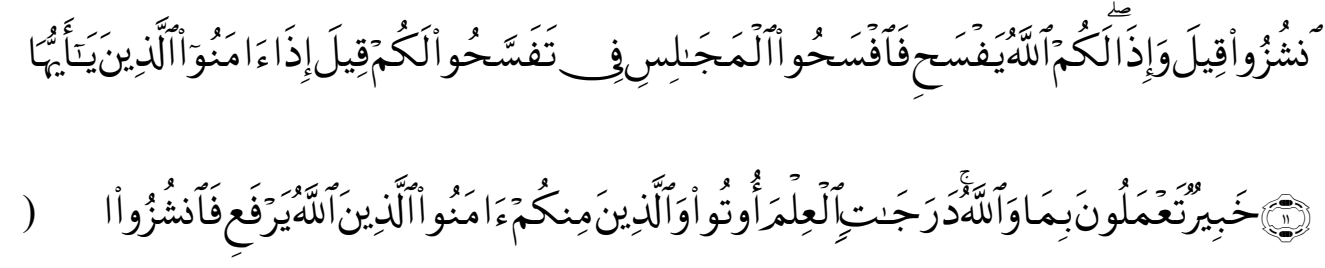

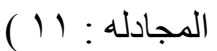

Artinya: "Hai orang-orang beriman apabila kamu dikatakan kepadamu: "Berlapang-lapanglah dalam majlis", Maka lapangkanlah niscaya Allah akan memberi kelapangan untukmu. dan apabila dikatakan: "Berdirilah kamu", Maka berdirilah, niscaya Allah akan meninggikan orang-orang yang beriman di antaramu dan orang-orang yang diberi ilmu pengetahuan beberapa derajat. dan Allah Maha mengetahui apa yang kamu kerjakan” (Al-Mujadalah : 11)

Di bawah ini, diterangkan hadits sebagai berikut :

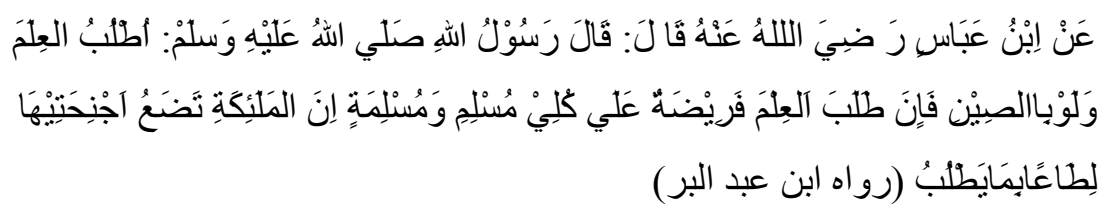


Farid Khoeroni

"Dari Ibnu Abbas ra ia berkata:Rosullulah SAW bersabda carilah ilmu sekalipun di negri cina,karena sesungguhnya mencariilmu itu wajib bagi seorang muslimlaki-laki dan perempuan dan sesungguhnyapara maaikat menaungkan sayapnya kepada orang yang menuntut ilmu karena ridho terhadap perbuatanya". (HR.ibnu abdul barr)

\section{Tujuan, Tugas dan Fungsi Pendidikan Islam}

Komponen-komponen sifat dasar (tabiat) manusia yang diakui adalah tubuh, ruh dan akal. Tujuan Pendidikan Islam secara umum dapat dibagi ke dalam tiga kelompok utama, antara lain yaitu: "tujuan jasmaniah (ahdaf al-jismiyyah), tujuan ruhani (ahdaf al-ruhaniyyah) dan tujuan mental (ahdaf al-aqliyyah)" (Abdullah, 1994: 137-151).

Sebagai pewaris budaya, "tugas Pendidikan Islam adalah alat transmisi unsurunsur pokok budaya dari satu generasi ke generasi berikutnya, sehingga identitas umat tetap terpelihara dan terjamin dalam tantangan zaman sebagai penghubung kebudayaan dari generasi ke generasi yang akan datang tidak jauh menyimpang dari nilai-nilai Islam, Pendidikan Islampun dapat menciptakan budaya-budaya baru yang sesuai dengan kondisi kemanusiaan dan lingkungannya" (Langgulung, 1980: 57). Sementara itu Achmadi menyimpulkan bahwa fungsi Pendidikan Islam, sebagai berikut :

1) Mengembangkan wawasan yang tepat dan benar mengenai jati diri manusia alam sekitarnya dan mengenai kebesaran illahi, sehingga tumbuh kemampuan membaca (analisis) fenomen alam dan kehidupan, serta memahami hukumhukum yang terkandung didalamnya

2) Membebaskan manusia dari segala anasir yang dapat merendahkan martabat manusia (fitrah manusia baik yang datang dari dalam dirinya sendiri maupun dari luar)"Mengembangkan ilmu pengetahuan untuk menopang dan memajukan kehidupan baik individu maupun sosial" (Ahmadi, 2005: 36-37). 
Farid Khoeroni

\section{Nilai Nilai Pendidikan Islam}

Pada dasarnya nilai pendidikan Islam secara umum memuat dua kategori yaitu, hablu min Allah dan hablu min an-nas. Dengan demikian ketika terfokus pada hablu min Allah, yang paling utama adalah terkait dengan ketakwaan kepada Allah. Sedangkan nilai yang berkaitan dengan hablu min an-nas maka nilai yang akan muncul adalah nilai yang berkaitan dengan sosial kemasyarakatan.

Batasan terkait dengan kedua nilai tersebut hanya berkaitan dengan nilai yang bersifat sosial kemasyarakatan. Sedangkan nilai yang berkaitan dengan hubungan dengan Allah merupakan nilai yang sudah bersifat final. Tidak terdapat perbedaan prinsip terkait dengannya. Batasan nilai yang berkaitan dengan nilai sosial kemasyarakatan merujuk pada pengertian pendidikan Islam yang memberikan batasan bahwa kata Islam sebagai penegas antara pendidikan Islam dengan pendidikan secara umum. Kemudian jika berkaitan dengan nilai yang bersifat sosial kemasyarakatan tentunya juga batasannya adalah tidak bertentangan dengan Islam. Jika bertentangan dengan Islam tidak lagi dapat dikategorikan sebagai nilai nilai pendidikan Islam.

Achmadi "mengemukakan contentPendidikan Islam berkaitan dengan nilai dan ilmu pengetahuan" (Ahmadi, 2005: 121-126).Pertama, Nilai terkait dengan kebaikan dan keburukan, berdasar tinjaua aksiologis, nilai dapat dikategorikan menjadi nilai bersifat mutlak dan nilai bersifat relative. Nilai yang bbersifat mutlak berkaitan dengan sesuatu yang tidak akan mengalami perubahan, tidak juga bergantung pada kondisi tertentu, dalam kondisi apapun nilai yang bersifat mutlak akan tetapa abadi. Kemudian nilai yang bersifat relative berkaitan dengan nilai yang terkondisikan oleh lingkungan sekitar. Lingkungan membentuk nilai sesuai karakter lingkungan tersebut. Menurut Ahmadi, nilai tertinggi dari content pendidikan Islam adalah nilai akhlak. Kedua, Ilmu pengetahuan. Allah telah memeberikan petunjuk melalui ayat ayat Qouliyah dan Kauniyah, dan dipersiapkan kepada manusia sesuai dengan fitrah manusia. Sesuai dengan sifat dasar manusia tentang rasa ingin tahu 


\section{Farid Khoeroni}

terhadap fakta serta realitas yang ada disekitar sesuai dengan petunjuk yang ada dalam Al Quran.

\section{Internalisasi Nilai Nilai Pendidikan Islam}

Internalisasi dimaknai sebagai penghayatan (KBBi, 2018). Selain itu arti internalisasi bermakna penghayatan terhadap suatu ajaran, doktrin, atau nilai sehingga merupakan keyakinan dan kesadaran akan kebenaran doktrin atau nilai yang diwujudkan dalam sikap dan perilaku (KBBI, 2018) Internalisasi ini juga bermakna berproses, artinya penghayatan mendalam suatu ajaran atau nilai-nilai beretujuan membentuk kepribadian manusia yang utuh (Rahmatulla, 2014).

Internalisasi nilai nilai pendidikan Islam sebagai upaya untuk mengcounter hoax melalui dua tahap. Tahap pertama adalah transformasi nilai, sedangkan tahapan kedua adalah terkait dengan orientasi perbaikan sikap dan mental. Keduanya merupakan sesuatu yang harus terpenuhi sebagai upaya mengcounter hoax. Saat ini hoax tidak dapat terdeteksi dengan system yang berkaitan dengan teknis kerja. Sedangkan mengcounter hoax yang berkaitan dengan karakter manusia itu sendiri sulit untuk diwujudkan.

Tahap pertama: transformasi nilai, transformasi berkaitan dengan nilai harus diwujudkan dalam aturan aturan yang berkaitan dengan perbaikan perbaikan akhlak sesuai dengan orientasi pendidikan Islam. Pada tahap ini seudah dilalui melalui proses pendidikan Islam, prosesnya sudah dijalani melalui pendididikan formal dan nonformal. Tahapan ini dapat dikatakan sudah pada tahapan final. Penyampaian informasi apapun terkait dengan nilai nilai pendidikan Islam sudah dilalui melalui proses pendidikan Islam.

Tahap kedua: pada tahap ini berkaitan dengan orientasi perbaikan akhlak. Tahapan ini bersifat aplikatif, sebenarnya secara teori tentang pendidikan Islam yang di dalamnya terdapat nilai nilai pendidikan Islam sudah dijalani melalui proses pendidikan formal dan non formal. Hanya kendalanya adalah teri yang diterima tidak sampai menginternalisasi sampai membentuk karakter. Karakter terbentuk melalui 


\section{Farid Khoeroni}

latihan terus menerus. Dengan latihan terus menerus nilai nilai pendidikan Islam akan terinternalisasi dan membentuk karakter manusia, sehinga dimanapun dan sampai kapanpun akan dapat survive dengan nilai nilai pendidikan Islam. Dengan terbentuknya karakter yang sesuai dengan nilai nilai pendidikan Islam, berita apapun yang berkaitan dengan ketidak benaran contentnya akan dapat dicari sumber kebenarannya dengan proses klarifikasi dan dengan bentuk lainnya.

\section{Kesimpulan}

Ketidakbenaransuatu beritaakan berdampak pada kehidupan masyarakat secara lebih luas, jauh hari sebelum hoax ramai menjadi pembicaraan dari berbagai kalangan. Hoax sebenarnya sudah ada jauh hari sebelum ramai diperbincangkan. Hanya saja terdapat perbedaan dari efek yang ditimbulkan dari hoax tersebut, yaitu berpengaruh secara luas atau tidak yang mana dampaknya sangat sulit diprediksi. Dalam skala besar, hoax akan menyasar isu isu yang akan berdampak pada sesuatu yang bersifat negatif. Hoax dapat dicounter melalui internalisasi nilai nilai pendidikan Islam, teknisnya ada dua tahap. Pertama: transformasi nilai nilai pendidikan Islam dan kedua adalah tahapan aplikatif berorientasi pada perbaikan sikap dan akhlak.

\section{Daftar Pustaka}

Al-Syaibani, O. M. Al-Toumy. (1979).Falsafah Pendidikan Islam. Jakarta: Bulan Bintang.

An Nakhlawi, A. (1992).Prinsip-prinsip dan Metode Pendidikan Islam. Bandung: CV Diponegoro.

Arifin, M.(1996). Filsafat Pendidikan Islam. Jakarta: Bumi Aksara.

Bawani, I.(1990). Tradisionalisme dalam Pendidikan Islam. Surabaya: al-Ikhlas.

Departemen Agama RI. (2000). Al Quran dan Terjemahnya.Jakarta: Depag RI. 
Farid Khoeroni

Departemen Agama RI. (2000).Al Quran dan Terjemahnya. Jakarta: Depag RI.

Elfindri dkk.(2010). Soft Skills untuk Pendidik. Padang: Baduose Media.

Firmansyah, R. (2017). Web Klarifikasi Berita Untuk Meminimalisir Penyebaran Berita Hoax. Revisi Agustus, 4(15).

Jalal, A. F. (1998).Asas-asas Pendidikan Islam. Terj. Harry Noer Aly. Bandung: CV Diponegoro.

Khon, A. M. (2014). Hadist Tarbawi. Jakarta: Kencana Prenada Media.

Langgulung, H.(1985). Pendidikan dan Peradaban Islam. Bandung: Pustaka Al Husna . (1992).Asas-Asas Pendidikan Islam. Jakarta: Pustaka Al- Husada.

Marimba, A. D. (1980).Pengantar Filsafat Pendidikan Islam. Bandung: Al Maarif.

Rahadi, D. R. (2017). Perilaku Pengguna dan Informasi Hoax di Media Sosial. Jurnal Manajemen Dan Kewirausahaan, 5, 58-70.

Rahmatulla, A. S. (2014). Internalisasi Nilai Gender melalui Dolanan Anak Tradisional, 2, 365-388. https://doi.org/10.14421/jpi.2014.32.365-388

https:/www.cnnindonesia.com/teknologi/20170213141029-185-193163/survei-masyarakatmasih-kesulitan-identifikasi-konten-hoax/ (diakses tanggal 25 November 2017)

https://inet.detik.com/cyberlife/d-3421124/survei-84-responden-terganggu-wabah-hoax (diakses tanggal 25 November 2017) 